\section{European cooperation}

\section{Eureka gets down to business}

EUREKA, the long-heralded but somewhat formless European programme of industrial cooperation on high-technology products, came a little more into shape on Monday, with the ministerial conference in London that marked the end of Britain's six-month secretaryship of the programme and the approval of over 60 new projects costing some 2.000 million ECU $(£ 1,300$ million $)$.

Industry, it seems, is beginning to take Eureka seriously as a means of developing products - such as metal-working carbon dioxide lasers and advanced road vehicle guidance and communications systems -that can take a slice not only of Europe's market of 400 million consumers but also of the 120 million in Japan and the 240 million in the United States. Governments are involved because they can use their political weight to help remove trade barriers and develop common standards. Already five or six of the projects approved on Monday involve requests for additional political support of that kind. British officials say.

Monday's meeting, opened with evident enthusiasm by British Prime Minister Margaret Thatcher, approved a fivefold increase in the number of Eureka projects since the last ministerial conference in November, and established a significantly tiny secretariat of seven civil servants in appropriately - Archimedes' Street in Brussels. The significance of the size of secretariat was that-governments are determined not to create "another bureaucracy" but merely a clearing house for projects proposed by industry itself.

Research is not a problem. Europe's research laboratories "burst with talent and imagination", said Mrs Thatcher, but the old continent fell down in turning this into market success. To change that, Eureka is encouraging companies to share development. But Eureka "was not a source of funds" said Thatcher (this despite the efforts by some smaller countries and Italy to establish a central European funding system for the programme). Rather, Eureka seems set to develop with governments providing support only for their national companies within particular cooperations; a system which will clearly favour the larger countries.

The British government is setting aside no new money for Eureka, but, according to technology minister Geoffrey Pattie, it will find some $£ 10$ million a year from within the Department of Trade and Industry's "Support for Innovation" scheme to back the British companies in 28 Eureka projects. These projects, including company and other national support, will account for some $£ 750$ million of new technology development over the next

\section{Laboratory safety}

five years or so. Pattic indicated. But onethird of the Eureka projects involving Britain have no government support at all. said Pattic. West German government support is said to be on a similar scale. Italian research minister Luigi Granclli said on Monday that he "guaranteed" that every high quality proposal will get government support. but put no scale to funding which must finally pass a sceptical ministry of finance. Italian forcign minister Andreotti also hinted that Italian companies must beef up their proposals: there is no point in getting involved in Eureka "merely as a matter of prestige", he sald. Meanwhile, the backing for Eureka in France, where the project originated 18 months ago, remains strong politically but uncertain financially, in a country which recently slashed its research and technology spending. Other countries, a total of 19 in all. including Iceland which joined on Monday, plan backing in proportion to the interest of their national companies.

Monday's meeting promised clarifica-

tion of one long-standing issue, the relationship of Eurcka to the European Commission's own international rescarch and development programme. According to Pattic. who for the next six months. which mark Britain's presidency of the European Council of Ministers, will chair the council of research ministers controlling the Commissions's programme, "it is quite clear there will be a linkage between certain Eureka projects and the Commission's programme". According to Research Commissioner Karl-Heinz Narjes. the programmes can be complementary because the Commission's programmes are pre-competitive and Eureka's clearly competitive.

A senior commission official at the meeting said there could still be " considerable differences" in arranging cooperation between Eureka and Commission programmes, however. For example, the two large environmental projects (EUROMAR on sea pollution and EUROTRAC on tracing air pollution) included in Eureka on West Germany`s insistence overlap strongly with Commission rescarch and are not aimed at winning markets.

Robert Walgate

\title{
Just how hot is Harvard?
}

\section{Boston, Massachusetts}

HAVE the mistakes in the management of radioactive materials, for which Harvard University last month received a $\$ 2.500$ fine from the Nuclear Regulatory Commission (NRC) been corrected? Harvard vice-president Robert Scott says they have. But graduate students in the medical research area have a different tale to tell. Left unresolved, according to the students, all of whom were unwilling to be named, is the pervasive mishandling of radioactive materials stemming from short cuts taken because of research pressure and inadequate training.

"Safety regulations are often perceived as a waste of time, standing in the way of a Nobel prize", said one student. The risks of this approach are high - a laboratory stripped of its NRC licence loses its research edge as well as its personnel - yet a fear of a loss of prestige could cause management to look the other way. Dr Warren Wacker, director of Harvard's University Health Services, denies such blinkering at Harvard. Using radioactivity is a privilege, he said, and he would brook "no nonsense and no pressure" in its management. As proof, he pointed to the three well-known laboratories in microbiology and AIDS (acquired immune deficiency syndrome) research that have just lost their licences for such infractions as inadequate cleaning of a spill.

NRC fined Harvard, according to an internal memorandum by its office of in- spection and enforcement. less because of the twelve specific incidents cited than for "lack of effective management control and oversight" of radioactivity. As a result, the violations that occurred were of particular concern to NRC because " they could have resulted in unnecessary radiation exposure to individuals"

By law, NRC can fine nuclear power plants up to $\$ 100.0(0)$ per infraction per day, but academic institutions only $\$ 5.0(0)$. On a severity scale of $1-5$. Harvard's infractions were rated as 3. for which the highest fine is $\$ 2.5()()$. Harvard has been warned about a number of other incidents. but they were not deemed serious enough to warrant a fine.

NRC. says Wacker, is cracking down on universities and Harvard, which is paying its fine without appeal, is not resisting. The salaries of two additional radiation health safety engineers will come from grants. not overhead. Other elements in Wacker's "model" programme will be continued - including surprise visits by Harvard's radiation service and immediate cancellations of licences for any serious infractions.

Radioactive materials are used on a daily basis in many medical research departments. amounting to "a couple of millicuries a week". Still. claims Wacker. "the highest level of radioactivity at Harvard is probably in the geology department in uranium ores, which are perfectly legal".

Elizabeth Collin 